Provided for non-commercial research and education use. Not for reproduction, distribution or commercial use.

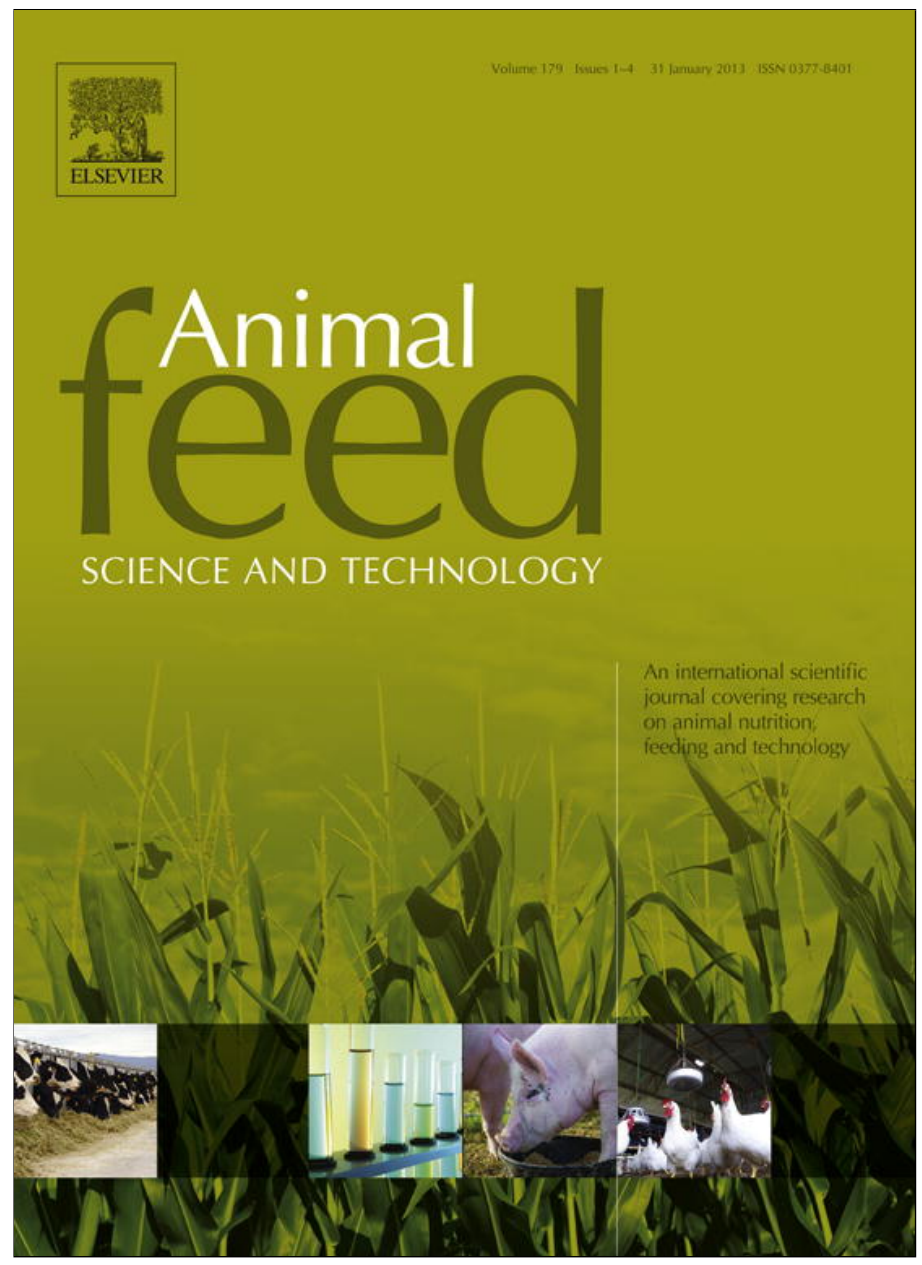

This article appeared in a journal published by Elsevier. The attached copy is furnished to the author for internal non-commercial research and education use, including for instruction at the authors institution and sharing with colleagues.

Other uses, including reproduction and distribution, or selling or licensing copies, or posting to personal, institutional or third party websites are prohibited.

In most cases authors are permitted to post their version of the article (e.g. in Word or Tex form) to their personal website or institutional repository. Authors requiring further information regarding Elsevier's archiving and manuscript policies are encouraged to visit:

http://www.elsevier.com/copyright 


\title{
Effects of exogenous enzymes on in vitro gas production kinetics and ruminal fermentation of four fibrous feeds
}

\author{
M.M.Y. Elghandour a ${ }^{\mathrm{a}}$ A.Z.M. Salem ${ }^{\mathrm{a}, \mathrm{d}, *}$, M. Gonzalez-Ronquillo ${ }^{\mathrm{a}}$, J.L. Bórquez ${ }^{\mathrm{a}}$, H.M. Gado ${ }^{\mathrm{b}}$, \\ N.E. Odongo ${ }^{c}$, C.G. Peñuelas ${ }^{a}$ \\ a Facultad de Medicina Veterinaria, Universidad Autónoma del Estado de México, México, Mexico \\ b Department of Animal Production, Faculty of Agriculture, Ain Shams University, Cairo, Egypt \\ c Animal Production and Health Section, Joint FAO/IAEA Division of Nuclear Techniques in Food and Agriculture, International Atomic Energy Agency, \\ Vienna, Austria \\ d Faculty of Agriculture (EL-Shatby), Alexandria University, Egypt
}

\section{A R T I C L E I N F O}

\section{Article history:}

Received 10 June 2012

Received in revised form

28 November 2012

Accepted 29 November 2012

\section{Keywords:}

Fibrous feeds

Gas production

Enzymes

Ruminal fermentation

\begin{abstract}
A B S T R A C T
This study was conducted to investigate effects of increasing doses: 0 (control), 6 (low), 12 (medium) and 24 (high) $\mathrm{mg} / \mathrm{g}$ DM of ZADO ${ }^{\circledR}$ enzyme preparation mixture (ENZ) on in vitro gas production (GP) and some ruminal fermentation parameters of the fibrous feeds Saccharum officinarum (leaves), Andropogon gayanus (leaves), Pennisetum purpureum (leaves) and Sorghum vulgare (straw). Rumen liquor was obtained from two Brown Swiss cows fitted with permanent rumen cannulae fed a total mixed ration of a 500:500 commercial concentrate and alfalfa hay ad libitum. The GP was recorded at 2, 4, 6, 8, 10, 12, 24, 48, 72 and $96 \mathrm{~h}$ of incubation. After $96 \mathrm{~h}$, the incubation was stopped and the $\mathrm{pH}$ of the mixture was determined and filtrate used to determine dry matter degradability (DMD), partitioning factor $\left(\mathrm{PF}_{96}\right)$, gas yield $\left(\mathrm{GY}_{24}\right)$, in vitro organic matter digestibility (OMD), metabolizable energy (ME), short chain fatty acids (SCFA), and microbial crude protien production (MCP). In general, the crude protein (CP) content of the fibrous feeds was low and ranged from $23 \mathrm{~g} / \mathrm{kg}$ DM (S. officinarum) to 44 (A. gayanus). The fibre contents (i.e., NDFom and ADFom) were highest $(\mathrm{P}<0.05)$ in $S$. officinarum. Increasing ENZ dose linearly increased $(\mathrm{P}<0.05)$ GP of all fibrous feeds and had a quadratically increased $(\mathrm{P}<0.05)$ asymptotic gas production in $P$. purpureum and $S$. vulgare and rate of gas production in S. officinarum and $S$. vulgare. Addition of ENZ also quadratically increased $(\mathrm{P}<0.05) \mathrm{GP}$ at all incubation times in S. officinarum and $S$. vulgare, and A. gayanus, but only at $72 \mathrm{~h}$ in A. gayanus. The parameters of ruminal fermentation of OMD, ME, $\mathrm{GY}_{24}$ and SCFA linearly increased $(\mathrm{P}<0.05)$ and $\mathrm{MCP}$ linearly decreased $(P<0.05)$ with the ENZ addition. Addition of enzyme affected ruminal fermentation of our feeds differently, mainly dependent on their fibre content, although dosage of enzyme was also important as impacts generally increased at higher dosages of ENZ.
\end{abstract}

Crown Copyright $@ 2012$ Published by Elsevier B.V. All rights reserved.

Abbreviations: ADFom, acid detergent fibre; CP, crude protein; DM, dry matter; DMD, DM degradability; ENZ, the ZADO ${ }^{\circledR}$ enzyme preparation mixture; GP, gas production; $\mathrm{GY}_{24}$, gas yield at $24 \mathrm{~h}$ of incubation; OM, organic matter; OMD, in vitro OM digestibility; MCP, microbial CP production; ME, metabolizable energy; NDFom, neutral detergent fibre; PF96, partitioning factor at $96 \mathrm{~h}$ of incubation; SCFA, short chain fatty acids.

* Corresponding author at: Facultad de Medicina Veterinaria, Universidad Autónoma del Estado de México, México. Tel.: +521 722 296 5542 ; fax: +5217221806194.

E-mail address: asalem70@yahoo.com (A.Z.M. Salem). 


\section{Introduction}

Digestion of plant cell walls in fibrous feeds by ruminants is possible mainly due to the enzymes produced by ruminal bacteria, protozoa and fungi. Several studies have focused on improving degradation of fibrous feeds in ruminants using feed additives; ionophores, direct fed microbials and cell wall degrading enzymes, or by using exogenous fibre degrading enzymes to stimulate rumen digestive microorganism's activities (Newbold, 1997; Kung et al., 2000; Nsereko et al., 2002; Giraldo et al., 2004). Fibrous feeds have high cellulose and hemicellulose concentrations that can create a complex of structural carbohydrates and lignin to reduce the digestibility of the carbohydrates and reduce efficient utilization of forages by ruminants. Exogenous fibrolytic enzymes may improve the nutritive value of fibrous feeds due to enhanced attachment by rumen microorganisms (Nsereko et al., 2002), creation of a stable enzyme feed complexes (Kung et al., 2000), and/or the possibility of alteration in the fibre structure, which could stimulate microbial colonization (Newbold, 1997; Giraldo et al., 2004).

However, effect of exogenous enzyme addition is influenced by factors such as diet composition, type of enzyme preparation, enzyme stability, specific enzyme activities, method of application and amount of enzyme added (Yang et al., 2000; Morgavi et al., 2001; Wallace et al., 2001). Non-linear impacts of enzyme addition has been well established in vivo (Lewis et al., 1999; Kung et al., 2000) and in vitro (Colombatto et al., 2003a,b) with higher levels of enzyme addition having reducing impacts that depend on the substrate used (Yang et al., 2000). The ZADO ${ }^{\circledR}$ enzyme mixture contains 7.1 units/g of endoglucanase, 2.3 units/g of xylanase, 61.5 units/g of $\alpha$-amylase and 29.2 units/g of protease activity, and has been used in in vivo experiments with goats (Gado, 1997), lambs (Gado et al., 2011) and dairy cows (Gado et al., 2009) to improve nutrient digestibility and ruminal fermentation parameters (Gado et al., 2009, 2011), microbial crude protein synthesis and milk production in cows by 23\% (Gado et al., 2009), and average daily gain in lambs by 92\% (Gado et al., 2011). However no information is available on use of ZADO ${ }^{\circledR}$ in vitro.

The aim of this study was to determine effects of increasing doses of the ZADO ${ }^{\circledR}$ enzyme mixture on in vitro gas production and some ruminal fermentation parameters of the fibrous feeds of Saccharum officinarum, Andropogon gayanus, Pennisetum purpureum and Sorghum vulgare.

\section{Materials and methods}

\subsection{Fibrous feed species and enzyme mixture preparation}

Three individual samples of each of the fibrous feeds Saccharum officinarum (leaves), Andropogon gayanus (leaves), Pennisetum purpureum (leaves) and Sorghum vulgare (straw) were randomly and manually harvested in triplicate from different sites in the State of Mexico. Samples were dried at $60^{\circ} \mathrm{C}$ for $48 \mathrm{~h}$ in a forced air oven to constant weight, ground in a Wiley mill to pass a $1 \mathrm{~mm}$ sieve and stored in plastic bags for subsequent determination of chemical components and in vitro gas production. Three levels of ZADO ${ }^{\circledR}$ (ENZ) a powdered multi-enzyme commercially available feed additive produced from Ruminococcus flavefaciens by the Academy of Scientific Research and Technology in Egypt (Patent No.: 22155, Cairo, Egypt) were used. Doses of ENZ were (/gDM): control $(0 \mathrm{mg})$, low $(6 \mathrm{mg})$, medium $(12 \mathrm{mg})$ and high (24 mg). Prior to the study, the enzyme mixture was assayed for several enzymatic activities and was found to contain (/g of enzyme preparation) 7.1 units of endoglucanase, 2.3 units of xylanase, 61.5 units of $\alpha$-amylase and 29.2 units of protease activity.

\subsection{In vitro incubations}

Rumen inoculum was collected from two Brown Swiss cows (400-450 kg body weight) fitted with permanent rumen cannula and fed ad libitum a total mixed ration made up of 500:500 commercial concentrate (PURINA ${ }^{\circledR}$, Toluca, Mexico) and alfalfa hay formulated to meet all of their nutrient requirements (NRC, 2001). Fresh water was available to cows at all times during the rumen inoculum collection phase.

Ruminal contents from each cow was obtained before the morning feeding, mixed and strained through four layers of cheesecloth into a flask with $\mathrm{O}_{2}$ free headspace. Samples of each feed were weighed into $120 \mathrm{ml}$ serum bottles with appropriate addition of ENZ doses/g DM. Consequently, $10 \mathrm{ml}$ of particle free ruminal fluid was added to each bottle followed by $40 \mathrm{ml}$ of the buffer solution according to Goering and Van Soest (1970), with no trypticase added, in a 1:4 (v/v) proportion.

A total of 432 bottles ( 3 bottles of each triplicate sample for each of the four feeds in three runs in different weeks with each dose of ENZ (i.e., 0, 6, 12, and $24 \mathrm{mg}$ ENZ/g DM) plus three bottles as blanks (i.e., rumen fluid only), were incubated for $96 \mathrm{~h}$. Once all bottles were filled, they were immediately closed with rubber stoppers, shaken and placed in the incubator at $39^{\circ} \mathrm{C}$. The volume of gas produced was recorded at times of 2, 4, 6, 8, 10, 12, 24, 48, 72 and $96 \mathrm{~h}$ of incubation using the pressure reading technique (Extech Instruments, Waltham, USA) of Theodorou et al. (1994). At the end of incubation (i.e., $96 \mathrm{~h}$ ), bottles were uncapped, $\mathrm{pH}$ was measured using a $\mathrm{pH}$ meter (Conductronic pH15, Puebla, Mexico) and the contents of each bottle were filtered to obtain the non-fermented residue for the determination of degraded substrate. 


\subsection{Dry matter degradability}

At the end of incubation (i.e., $96 \mathrm{~h}$ ), the contents of each serum bottle were filtered under vacuum through glass crucibles with a sintered filter (coarse porosity no. 1, pore size 100-160 $\mu \mathrm{m}$, Pyrex, Stone, UK). Fermentation residues were dried at $105^{\circ} \mathrm{C}$ overnight to estimate DM disappearance with loss in weight after drying being the measure of undegradable DM.

\subsection{Chemical analyses and assay of enzymatic activity}

Samples of the feeds were analyzed for DM (\#934.01), ash (\#942.05), N (\#954.01) and EE (\#920.39) according to AOAC (1997). The neutral detergent fibre (NDFom, Van Soest et al., 1991), acid detergent fibre (ADFom) and lignin(sa) (AOAC, 1997; \#973.18) analyses used an ANKOM200 Fiber Analyzer Unit (ANKOM Technology Corp., Macedon, NY, USA). NDFom was assayed without use of an alpha amylase but with sodium sulfite in the NDFom. Both NDFom and ADFom are expressed without residual ash.

Enzyme activities in the enzyme preparation (i.e., ENZ) were determined. Endoglucanase was determined according to Robyt and Whelan (1972), $\alpha$-amylase was according to Bernfeld (1955), protease by Lin et al. (1969), and xylanase activity by Robyt and Whelan (1972) by catalyzing the hydrolysis of xylan from oat spelt, with the reducing groups liberated determined using alkaline copper reagent.

\subsection{Calculations}

To estimate kinetic parameters of GP, results ( $\mathrm{ml} / \mathrm{g}$ DM) were fitted using the NLIN option of SAS (2002) according to France et al. (2000) as:

$$
A=b \times\left(1-e^{-c(t-L)}\right)
$$

where $A$ is the volume of GP at time $t ; b$ is the asymptotic GP ( $\mathrm{ml} / \mathrm{g} \mathrm{DM}) ; c$ is the rate of GP $(/ \mathrm{h})$, and $L(\mathrm{~h})$ is the discrete lag time prior to gas production.

Metabolizable energy ( $\mathrm{ME}, \mathrm{MJ} / \mathrm{kg} \mathrm{DM})$ and in vitro organic matter digestibility (OMD, g/kg OM) were estimated according to Menke et al. (1979) as:

$$
\begin{aligned}
& \mathrm{ME}=2.20+0.136 \mathrm{GP}(\mathrm{ml} / 0.5 \mathrm{~g} \mathrm{DM})+0.057 \mathrm{CP}(\mathrm{g} / \mathrm{kg} \mathrm{DM}) \\
& \mathrm{OMD}=148.8+8.89 \mathrm{GP}+4.5 \mathrm{CP}(\mathrm{g} / \mathrm{kg} \mathrm{DM})+0.651 \mathrm{ash}(\mathrm{g} / \mathrm{kg} \mathrm{DM})
\end{aligned}
$$

where GP is net GP in $\mathrm{ml}$ from $200 \mathrm{mg}$ of dry sample after $24 \mathrm{~h}$ of incubation.

The partitioning factor at $96 \mathrm{~h}$ of incubation ( $\mathrm{PF}_{96}$; a measure of fermentation efficiency) was calculated as the ratio of DM degradability in vitro (DMD, $\mathrm{mg}$ ) to the volume ( $\mathrm{ml}$ ) of GP at $96 \mathrm{~h}$ (i.e., DMD/total gas production (GP96)) according to Blümmel et al. (1997). Gas yield $\left(\mathrm{GY}_{24}\right)$ was calculated as the volume of gas ( $\mathrm{ml}$ gas/g DM) produced after $24 \mathrm{~h}$ of incubation divided by the amount of DMD (g) as:

$$
\text { gas yield }\left(\mathrm{GY}_{24}\right)=\frac{\mathrm{ml} \text { gas/g DM }}{\mathrm{g} \mathrm{DMD}}
$$

Short chain fatty acid concentrations (SCFA) was calculated according to Getachew et al. (2002) as:

$$
\mathrm{SCFA}(\mathrm{mmol} / 200 \mathrm{mg} \mathrm{DM})=0.0222 \mathrm{GP}-0.00425
$$

where GP is the $24 \mathrm{~h}$ net gas production ( $\mathrm{ml} / 200 \mathrm{mg} \mathrm{DM})$.

Microbial CP biomass production was calculated according to Blümmel et al. (1997) as:

$$
\mathrm{MCP}(\mathrm{mg} / \mathrm{g} \mathrm{DM})=\mathrm{mg} \mathrm{DMD}-(\mathrm{ml} \text { gas } \times 2.2 \mathrm{mg} / \mathrm{ml})
$$

where $2.2 \mathrm{mg} / \mathrm{ml}$ is a stoichiometric factor which expresses $\mathrm{mg}$ of $\mathrm{C}, \mathrm{H}$ and $\mathrm{O}$ required for the production of SCFA gas associated with production of $1 \mathrm{ml}$ of gas.

\subsection{Statistical analyses}

The experimental design for the in vitro ruminal GP and fermentation parameter analyses was a completely random design considering, as fixed factors, type of forage $(S)$ and enzyme preparation level $(Z)$ in the linear model (Steel et al., 1997). Data of each of the three runs within the same sample were averaged prior to statistical analysis. Mean values of each individual sample within each species (three samples of each) were used as the experimental unit (Udén et al., 2012). The statistical model was:

$$
Y_{i j k l}=\mu+S_{j}+Z_{k}+(S \times Z)_{j k}+E_{i j k l}
$$

where $Y_{i j k}=$ is every observation of the $i$ th fibrous specie $\left(S_{i}\right)$ when incubated in the $j$ th ENZ doses $\left(Z_{j}\right.$; enzyme preparation); $\mu$ is the general mean; $S_{i}(i=1-4)$ is the feed effect; $Z_{j}$ is the enzyme dose effect $(j=1-4)$; $(S Z)_{i j}$ is the interaction between feed 
Table 1

Chemical composition ${ }^{\mathrm{a}}$ of the four fibrous feeds ( $\left.\mathrm{g} / \mathrm{kg} \mathrm{DM}\right)$.

\begin{tabular}{|c|c|c|c|c|}
\hline Species & $\mathrm{OM}$ & $\mathrm{CP}$ & ADFom & NDFom \\
\hline Saccharum officinarum (leaves) & 948 & $23 b$ & $482 \mathrm{a}$ & $698 a$ \\
\hline Andropogon gayanus (leaves) & 881 & $44 a$ & 410b & $579 c$ \\
\hline Pennisetum purpureum (leaves) & 944 & $40 a$ & $378 b$ & $557 c$ \\
\hline Sorghum vulgare (straw) & 930 & $43 a$ & $386 b$ & $614 b$ \\
\hline SEM & 52.3 & 7.3 & 26.1 & 35.1 \\
\hline
\end{tabular}

a OM: organic matter, CP: crude protein, ADFom, acid detergent fibre, NDFom, neutral detergent fibre.

Different letters ( $\mathrm{a}, \mathrm{b}, \mathrm{c}$ ) following means within column indicate differences at $\mathrm{P}<0.05$.

and enzyme dose; and $E_{i j k}$ is experimental error. Linear and quadratic polynomial contrasts were used to examine responses of feeds to increasing addition levels of the enzyme preparation.

\section{Results}

In general, the $\mathrm{CP}$ content of the feeds was low (Table 1) ranging from 23 (S. officinarum) to 44 (A. gayanus) g/kg DM. Fibre content (i.e., NDFom and ADFom) were highest for S. officinarum.

Increasing ENZ dose, linearly increased $(\mathrm{P}<0.05)$ GP of all feeds, increased $(\mathrm{P}<0.05$, quadratic effect) asymptotic gas production in P. purpureum and $S$. vulgare, and increased $(\mathrm{P}<0.05$, quadratic effect) rate of gas production in $S$. officinarum and S. vulgare (Table 2 and Fig. 1). The lag was not affected by ENZ addition.

Addition of ENZ increased ( $\mathrm{P}<0.05$, quadratic effect) GP at all incubation times in $S$. officinarum and $S$. vulgare and A. gayanus, except at $72 \mathrm{~h}$ in $A$. gayanus (Table 2 ).

Table 2

In vitro rumen gas kinetics and cumulative gas production after $96 \mathrm{~h}$ of incubation as affected by level of exogenous enzyme preparation (ENZ; mg/g DM).

\begin{tabular}{|c|c|c|c|c|c|c|c|c|c|c|}
\hline \multirow[t]{2}{*}{ Substrate (S) } & \multirow{2}{*}{$\begin{array}{l}\text { Enzyme } \\
\text { dosage } \\
\text { (ENZ) }\end{array}$} & \multicolumn{3}{|c|}{ Gas production parameters ${ }^{\mathrm{a}}$} & \multicolumn{6}{|c|}{ In vitro gas production (ml/g DM) } \\
\hline & & $b$ & $c$ & $L$ & $\mathrm{GP}_{6}$ & $\mathrm{GP}_{12}$ & $\mathrm{GP}_{24}$ & $\mathrm{GP}_{48}$ & $\mathrm{GP}_{72}$ & $\mathrm{GP}_{96}$ \\
\hline \multirow[t]{7}{*}{ Saccharum officinarum (leaves) } & 0 & 139 & 0.013 & 2.72 & 9.8 & 19.0 & 35.2 & 61 & 80.7 & 95.1 \\
\hline & 6 & 197 & 0.011 & 2.14 & 12.0 & 23.1 & 42.9 & 75 & 98.2 & 116.1 \\
\hline & 12 & 206 & 0.017 & 1.14 & 19.6 & 37.2 & 67.5 & 112 & 142.2 & 162.3 \\
\hline & 24 & 220 & 0.031 & 0.83 & 37.1 & 68.0 & 114.8 & 169 & 195.5 & 208.0 \\
\hline & $\mathrm{P}$ & & & & & & & & & \\
\hline & Linear & 0.659 & 0.454 & 0.544 & 0.047 & 0.050 & 0.056 & 0.071 & 0.084 & 0.072 \\
\hline & Quadratic & 0.341 & 0.001 & 0.079 & $<0.001$ & $<0.001$ & $<0.001$ & 0.001 & 0.002 & 0.001 \\
\hline \multirow[t]{5}{*}{ Andropogon gayanus (leaves) } & 0 & 233 & 0.010 & 1.31 & 13.2 & 25.7 & 48.5 & 87 & 117.2 & 141.2 \\
\hline & 6 & 222 & 0.017 & 1.32 & 21.2 & 40.4 & 73.2 & 122 & 154.2 & 175.9 \\
\hline & 12 & 239 & 0.017 & 1.73 & 22.7 & 43.2 & 78.6 & 131 & 166.7 & 190.5 \\
\hline & 24 & 234 & 0.051 & 1.41 & 47.5 & 81.2 & 125.9 & 175 & 201.0 & 215.4 \\
\hline & $\mathrm{P}$ & & & & & & & & & \\
\hline \multirow[t]{7}{*}{ Pennisetum purpureum (leaves) } & 0 & 152 & 0.019 & 1.44 & 16.7 & 31.6 & 56.6 & 92 & 114.4 & 128.3 \\
\hline & 6 & 183 & 0.019 & 1.47 & 19.7 & 37.2 & 66.9 & 109 & 136.3 & 153.4 \\
\hline & 12 & 208 & 0.019 & 1.66 & 22.2 & 42.1 & 75.7 & 124 & 154.6 & 174.1 \\
\hline & 24 & 257 & 0.018 & 1.33 & 24.2 & 45.5 & 81.0 & 131 & 162.4 & 183.4 \\
\hline & $\mathrm{P}$ & & & & & & & & & \\
\hline & Linear & 0.099 & 0.831 & 0.807 & 0.521 & 0.509 & 0.483 & 0.421 & 0.349 & 0.574 \\
\hline & Quadratic & 0.005 & 0.873 & 0.867 & 0.203 & 0.192 & 0.170 & 0.124 & 0.080 & 0.263 \\
\hline \multirow[t]{7}{*}{ Sorghum vulgare (straw) } & 0 & 245 & 0.020 & 1.75 & 27.7 & 52.2 & 93.3 & 151 & 186.8 & 208.9 \\
\hline & 6 & 240 & 0.026 & 1.17 & 33.8 & 62.9 & 109.2 & 169 & 201.2 & 218.9 \\
\hline & 12 & 255 & 0.027 & 1.75 & 38.5 & 71.0 & 122.0 & 185 & 217.9 & 235.2 \\
\hline & 24 & 280 & 0.030 & 1.58 & 46.1 & 84.6 & 143.5 & 213 & 247.3 & 264.0 \\
\hline & $\mathrm{P}$ & & & & & & & & & \\
\hline & Linear & 0.784 & 0.050 & 0.129 & 0.095 & 0.091 & 0.086 & 0.089 & 0.112 & 0.125 \\
\hline & Quadratic & 0.016 & 0.016 & 0.428 & 0.006 & 0.005 & 0.004 & 0.003 & 0.003 & 0.003 \\
\hline Pooled SEM & & 21.1 & 0.0070 & 0.464 & 3.77 & 5.76 & 8.24 & 12.2 & 14.91 & 13.21 \\
\hline \multicolumn{11}{|l|}{ P value } \\
\hline $\mathrm{S} \times \mathrm{ENZ}$ & & 0.45 & 0.22 & 0.38 & 0.05 & 0.03 & 0.04 & 0.20 & 0.48 & 0.16 \\
\hline
\end{tabular}

\footnotetext{
a $b$ is the asymptotic gas production $(\mathrm{ml} / \mathrm{g} \mathrm{DM}) ; c$ is the rate of gas production $\left(\mathrm{h}^{-1}\right)$; $L$ is the initial delay before gas production begins $(\mathrm{h})$.
} 

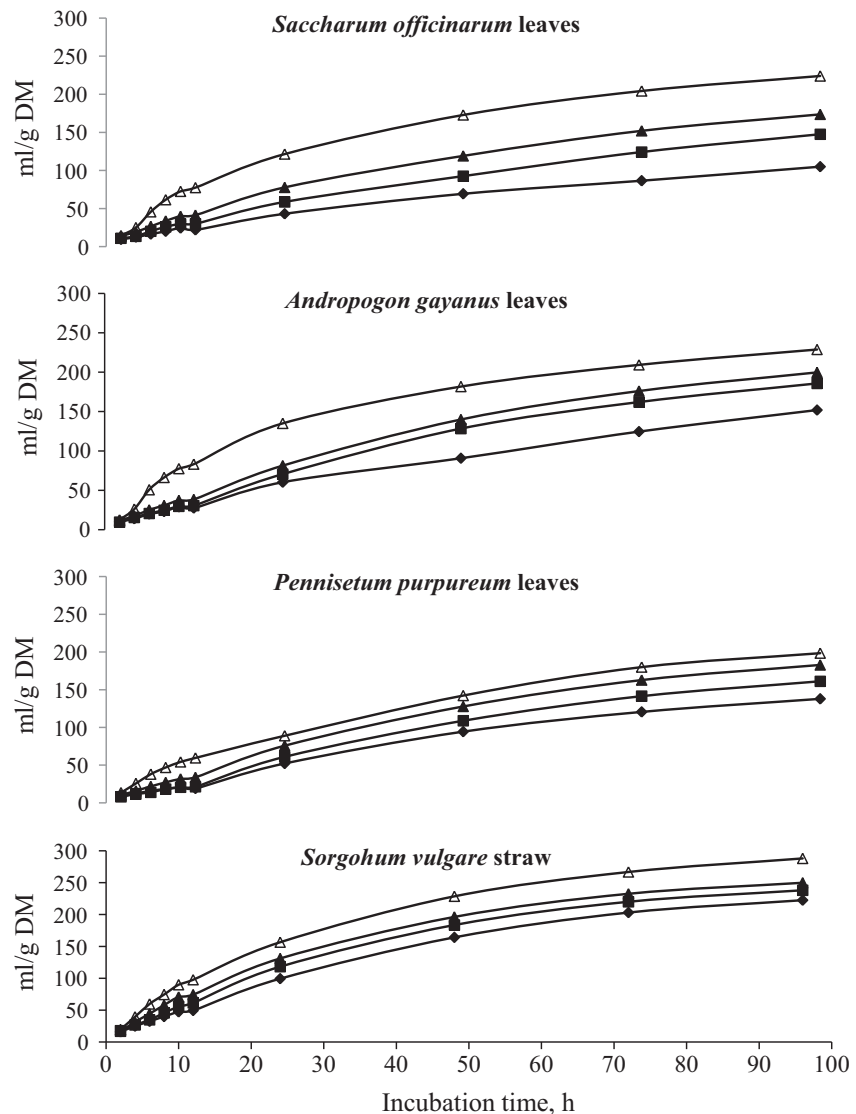

Fig. 1. Cumulative gas production profiles ( $\mathrm{ml}$ gas/g DM) from in vitro fermentation of four fibrous feed species at four doses of exogenous enzyme preparation (ENZ, mg/g DM) (- -, 0; -,$- 6 ;-\Delta-, 12 ;-\triangle-, 24 \mathrm{mg}$ ENZ/g DM of substrate; SEM is for the overall fit and $P^{\prime}$ is for the effect of enzyme dose).

Addition of ENZ, in general, increased ( $\mathrm{P}<0.05$, quadratic effect) parameters of ruminal fermentation, while final $\mathrm{pH}$ and MCP decreased ( $P<0.05$, quadratic effect). However, OMD, ME, GY 24 and SCFA linearly increased $(\mathrm{P}<0.05)$, and MCP decreased $(\mathrm{P}<0.05)$, with the addition of ENZ versus control (Table 3 ).

\section{Discussion}

Differences in CP contents between the feed were probably due to stage of maturity, the N profile of the soils where they were grown and differences in efficiency of protein accumulation in them during growth. However, the nutrient levels are comparable to those reported by Rubanza et al. (2003). Differences in nutrient composition of the feeds are also likely due to differences in the stage of growth and plant part (i.e., twigs, leaves, soft stem) sampled. Inconsistencies could also be due to sampling site and climatic influences on species growth and plant nutrient accumulation.

In general, GP appeared to be related to the chemical composition of the feeds, in particular to the fibre content (Table 2 and Fig. 1). Several studies have shown that adding this enzyme preparation to ruminant diets increased digestion of DM and fibre measured in situ, in vitro or in vivo (Gado, 1997; Gado et al., 2009, 2011; Salem et al., 2011). Increased in vitro GP with ENZ may allow higher voluntary feed intake (Gado et al., 2009) by decreasing physical rumen fill, increasing the net energy density of the diets and stimulating MCP production (Oba and Allen, 2000).

The ENZ addition was effective in improving in vitro GP (Table 2) and ruminal fermentation parameters such as $\mathrm{OMD}_{\text {, }} \mathrm{GY} 24$ and SCFA when applied to S. vulgare, which compared with smaller effects when it was added to S. officinarum, A. gayanus and $P$. purpureum. This effect could be due to differences in the internal plant cell wall structures of the feeds, but results are consistent with Yu et al. (2005) who found that responses of alfalfa hay, wheat straw and oat hulls to a multi-enzyme cocktail differed, and concluded that a multi-enzyme cocktail is most effective for oat hulls, followed by alfalfa hay lastly wheat straw.

The linear increase in GP of the feeds with increasing ENZ addition in S. officinarum and S. vulgare and A. gayanus at all the incubation times could support the hypothesis that a suitable enzyme dose could improve fermentation efficiency, and/or that ENZ addition stimulated fermentation (Nsereko et al., 2002). That the ENZ affected GP to the fermentation end point of $96 \mathrm{~h}$ (Fig. 1) could indicate that ENZ increased fermentable material (Colombatto et al., 2003b), which is inconsistent with Wang et al. (2004) who reported that $1.5 \mathrm{~g} / \mathrm{kg}$ of a fibrolytic multi-enzyme added to wheat straw only increased GP up to $8 \mathrm{~h}$ of incubation. The rapid and linear increase in GP with the addition of ENZ to these feeds, although it had no effect on lag time, could be due to addition of the polysaccharidase enzymes in ZADO ${ }^{\circledR}$ which provided fermentable carbohydrate 
M.M.Y. Elghandour et al. / Animal Feed Science and Technology 179 (2013) 46-53

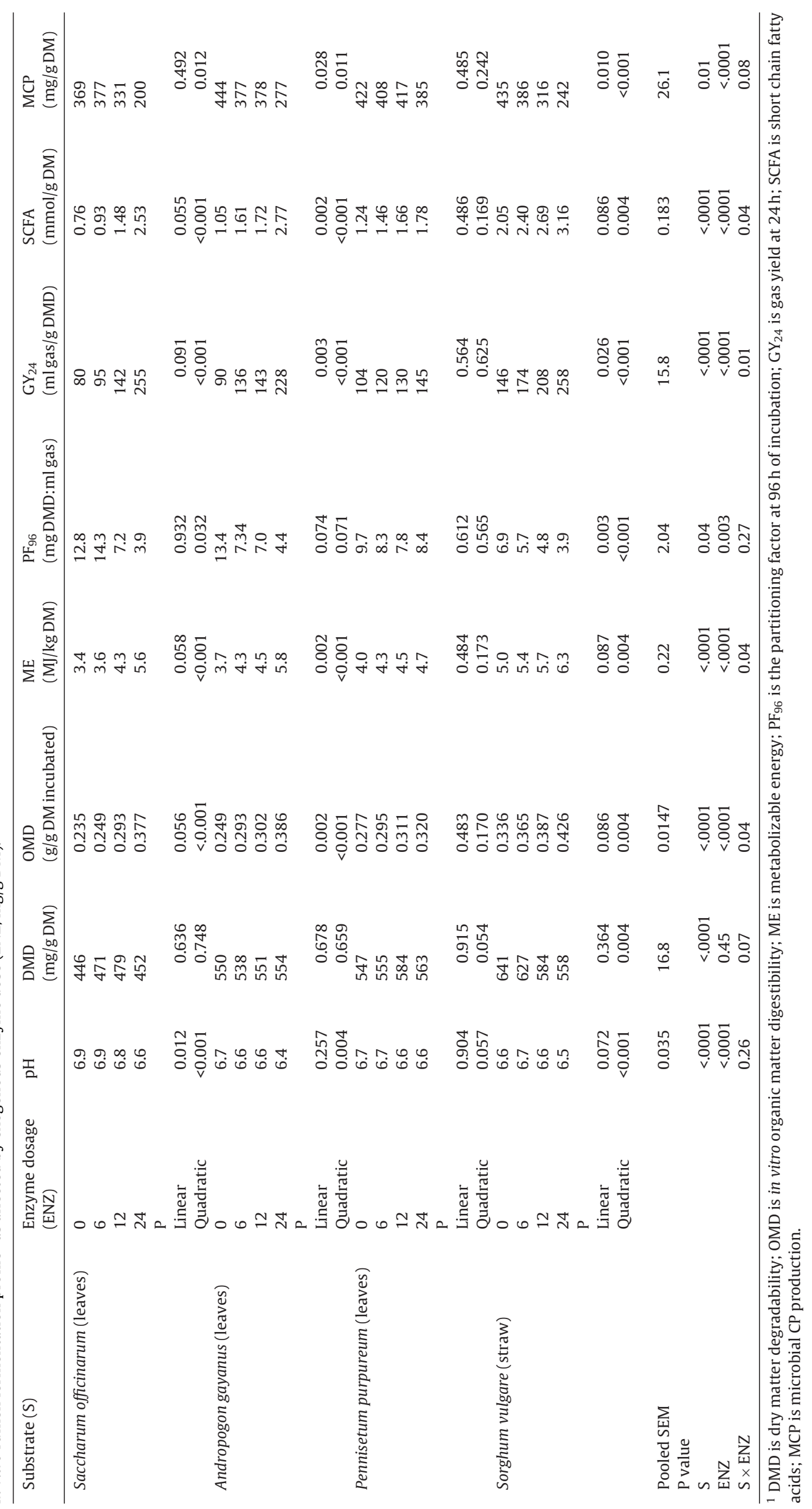


to stimulate microbial growth (Forsberg et al., 2000). It could also be due to the increased numbers of fibrolytic and nonfibrolytic bacteria in the rumen due to release of polysaccharides which are readily utilized by the bacteria (Nsereko et al., 2002).

We hypothesize that curvilinear increase in GP and fermentation kinetics of these feeds with increasing levels of ENZ was due to excessive levels of ENZ that may have prevented binding of all enzymes to substrate receptors, which reduced proportional attachment by ruminal microorganisms to fibre (Treacher and Hunt, 1996). Colombatto et al. (2003a) concluded that increasing the level of enzyme from $1 \times$ to $5 \times$ increased the rate and extent of GP, but that addition at the $10 \times$ levels was not effective.

The linear increase of DMD and OMD, ME, GY $\mathrm{GY}_{24}$ and SCFA of these feeds with the addition of ENZ may have been due to increased fibre digestion and altered ruminal fermentation (Nsereko et al., 2002), enhanced attachment and colonization to the plant cell wall material by rumen microorganisms (Nsereko et al., 2002; Wang et al., 2001) and/or by synergism between ruminal enzymes and the enzymes of the ENZ as the most likely mode of action of the enzyme (Morgavi et al., 2001). Indeed Morgavi et al. (2001) demonstrated synergism between exogenous and ruminal enzymes such that the net combined hydrolytic effect in the rumen was much higher than that estimated from individual enzyme activities. Increased SCFA with increased ENZ dose was opposite of the $\mathrm{pH}$ response, but is consistent with the increase OMD and ME. Our results also agree with Omar et al. (2009), who concluded that supplementation of enzymes to steer rations improved digestibility and rumen SCFA concentrations.

Addition of ENZ linearly decreased MCP compared with the control in all feeds. This may have been due to a poor synchronization between energy and $\mathrm{N}$ availability and a deficiency in $\mathrm{N}$ due to the generally low $\mathrm{CP}$ content of the feeds.

\section{Conclusions}

The effectiveness of the enzyme preparation differed among the feeds being highest for S. vulgare, intermediate A. gayanus and $P$. purpureum, and lowest for $S$. officinarum. Increasing the enzyme dose, linearly increased ruminal gas production including fermentation rate and asymptotic gas production, but decreased microbial CP production.

\section{Acknowledgments}

The authors acknowledge financial support from the IAEA, Vienna (Austria), Research Contract number MEX16307 within the D3.10.27 Coordinated Research Project. Elghandour, M.M. thank the National Council for Science and Technology (CONACYT, Mexico) for the scholarship for her Master in Science from the Universidad Autónoma del Estado de México.

\section{References}

Association of Official Analytical Chemists (AOAC), 1997. Official Methods of Analysis, 16th ed. AOAC, Arlington, VA, USA

Bernfeld, P., 1955. Amylases, alpha and beta. Methods. Enzymol. 1, 149-158.

Blümmel, M., Steingss, H., Becker, K., 1997. The relationship between in vitro gas production, in vitro microbial biomass yield and ${ }^{15} \mathrm{~N}$ incorporation and its implications for the prediction of voluntary feed intake of roughages. Br. J. Nutr. 77, 911-921.

Colombatto, D., Mould, F.L., Bhat, M.K., Morgavi, D.P., Beauchemin, K.A., Owen, E., 2003a. Influence of fibrolytic enzymes on the hydrolysis and fermentation of pure cellulose and xylan by mixed ruminal micro organisms in vitro. J. Anim. Sci. 81, 1040-1050.

Colombatto, D., Mould, F.L., Bhat, M.K., Owen, E., 2003b. Use of fibrolytic enzymes to improve the nutritive value of ruminant diets. A biochemical and in vitro rumen degradation assessment. Anim. Feed Sci. Technol. 107, 201-209.

Forsberg, C., Forano, E., Chesson, A., 2000. Microbial adherence to the plant cellwall and enzymatic hydrolysis. In: Cronje, P.B. (Ed.), Ruminant Physiology: Digestion, Metabolism, Growth and Reproduction. CABI Publishing, Wallingford, UK, pp. 79-97.

France, J., Dijkstra, J., Dhanoa, M.S., López, S., Bannink, A., 2000. Estimating the extent of degradation of ruminant feeds from a description of their gas production profiles observed in vitro: derivation of models and other mathematical considerations. Br. J. Nutr. 83, $143-150$.

Gado, H., 1997. Effect of enzymatic treatments for poor quality roughages on fiber digestibility and nitrogen metabolism in Baladi goats. Egypt. J. Nutr. Feeds, 50-56 (special issue).

Gado, H.M., Salem, A.Z.M., Odongo, N.E., Borhami, B.E., 2011. Effect of exogenous enzymes ensiled with orange pulp on digestion, blood metabolites and growth performance in lambs. Anim. Feed Sci. Technol. 165, 131-136.

Gado, H.M., Salem, A.Z.M., Robinson, P.H., Hassan, M., 2009. Influence of exogenous enzymes on nutrient digestibility, extent of ruminal fermentation as well as milk production and composition in dairy cows. Anim. Feed Sci. Technol. 154, 36-46.

Getachew, G., Makkar, H.P.S., Becker, K., 2002. Tropical browses: contents of phenolic compounds, in vitro gas production and stoichiometric relationship between short chain fatty acid and in vitro gas production. J. Agric. Sci. 139, 341-352.

Giraldo, L.A., Ranilla, M.J., Tejido, M.L., Carro, M.D., 2004. Effect of enzyme application method on in vitro rumen fermentation of tropical forages. J. Anim. Feed Sci. 13, 63-66.

Goering, M.K., Van Soest, P.J., 1970. Forage fiber analysis (apparatus, reagents, procedures and some applications). In: Agriculture Handbook, No. 379. Agricultural Research Service, USDA, Washington, DC, USA.

Kung Jr., L., Treacher, R.J., Nauman, G.A., Smagala, A.M., Endres, K.M., Cohen, M.A., 2000. The effect of treating forages with fibrolytic enzymes on its nutritive value and lactation performance of dairy cows. J. Dairy Sci. 83, 115-122.

Lin, Y., Gary, E., Robert, E., 1969. Action of proteolytic enzymes on N,N-dimethyl proteins. Basis for a micro-assay for proteolytic enzymes. J. Biol. Chem. 244, 789-793.

Lewis, G.E., Sanchez, W.K., Hunt, C.W., Guy, M.A., Pritchard, G.T., Swanson, B.I., Treacher, R.J., 1999. Effect of direct-fed fibrolytic enzymes on the lactational performance of dairy cows. J. Dairy Sci. 82, 611-617.

Menke, K.H., Raab, L., Salewski, A., Steingass, H., Fritz, D., Schneider, W., 1979. The estimation of the digestibility and metabolizable energy content of ruminant feeding stuffs from the gas production when they are incubated with rumen liquor in vitro. J. Agric. Sci. Camb. 93, 217-222.

Morgavi, D.P., Beauchemin, K.A., Nsereko, V.L., Rode, L.M., McAllister, T.A., Iwaasa, A.D., Wang, Y., Yang, W.Z., 2001. Resistance of feed enzymes to proteolytic inactivation by rumen micro organisms and gastrointestinal proteases. J. Anim. Sci. 79, 1621-1630. 
Newbold, J., 1997. Proposed mechanisms for enzymes as modifiers of ruminal fermentation. In: Proceedings of the 8th Annual Florida Ruminant Nutrition Symposium, Gainesville, FL, USA, pp. 146-159.

NRC, 2001. Nutrient Requirement of Dairy Cattle, 7th rev. ed. National Research Council/National Academy Press, Washington, DC, USA.

Nsereko, V.L., Beauchemin, K.A., Morgavi, D.P., Rode, L.M., Furtado, A.F., McAllister, T.A., Iwaasa, A.D., Yang, W.Z., Wang, Y., 2002. Effect of a fibrolytic enzyme preparation from Trichoderma longibrachiatum on the rumen microbial population of dairy cows. Can. J. Microbiol. 48, 14-20.

Oba, M., Allen, M.S., 2000. Effects of brown midrib 3 mutation in corn silage on productivity of dairy cows fed two concentrations of dietary neutral detergent fiber: 3. Digestibility and microbial efficiency. J. Dairy Sci. 83, 1350-1358.

Omar, H.A.A., Abd El-Rahman, H.H., Fatma, M., Salman, Soha, S., Abdel-Magid, Mohamed, M.I., Awadalla, I.M., 2009. Response of growing calves to diets containing different levels of exogenous enzymes mixture. Egypt. J. Nutr. Feeds 12 (3), 385-401.

Robyt, J.F., Whelan, W.J., 1972. Reducing value methods for maltodextrins: 1 . Chain length dependence of alkaline 3,5-dinitrosalicylate and chain length independence of alkaline copper. Anal. Biochem. 45, 510-516.

Rubanza, C.D.K., Shem, M.N., Otsyina, R., Ichinohe, T., Fujihara, T., 2003. Nutritive evaluation of some browse tree legume foliages native to semi-arid area in western Tanzania. Asian-Aust. J. Anim. Sci. 16, 1429-1437.

Salem, A.Z.M., El-Adawy, M.M., Gado, H.M., Camacho, L.M., González-Ronquillo, M., Alsersy, H., Borhami, B., 2011. Effects of exogenous enzymes on nutrients digestibility and growth performance in sheep and goats. Trop. Subtrop. Agroecosyst. 14, 867-874.

SAS, 2002. User's Guide: Statistics Ver 9.0. SAS Inst. Inc., Cary, NC, USA.

Steel, R.G.D., Torrie, J.H., Dickey, D.A., 1997. Principles and Procedures of Statistics. In: A biometrical approach, 3rd Ed. McGraw Hill Book Co, New York, USA.

Theodorou, M.K., Williams, B.A., Dhanoa, M.S., McAllan, A.B., France, J., 1994. A simple gas production method using a pressure transducer to determine the fermentation kinetics of ruminant feeds. Anim. Feed Sci. Technol. 48, 185-197.

Treacher, R.J., Hunt, C.W., 1996. Recent developments in feed enzymes for ruminant rations. In: Proc. Pacific Northwest Animal Nutrition Conference, Seattle, WA, USA, pp. 37-54.

Udén, P., Robinson, P.H., Mateos, G.G., Blank, R., 2012. Use of replicates in statistical analyses in papers submitted for publication in Animal Feed Science and Technology. Anim. Feed Sci. Technol. 171, 11-15.

Van Soest, P.J., Robertson, J.B., Lewis, B.A., 1991. Methods for dietary fiber, neutral detergent fiber and non-starch polysaccharides in relation to animal nutrition. J. Dairy Sci 74, 3583-3597.

Wang, Y., McAllister, T.A., Rode, L.M., Beauchemin, K.A., Morgavi, D.P., Nsereko, V.L., Iwaasa, A.D., Yang, W., 2001. Effects of an exogenous enzyme preparation on microbial protein synthesis, enzyme activity and attachment to feed in the Rumen simulation technique (Rusitec). Br. J. Nutr. 85, 325-332.

Wang, Y., Spartling, B.M., Zobell, D.R., Wiedmeier, R.D., McAllister, T.A., 2004. Effect of alkali pre-treatment of wheat straw on the efficacy of exogenous fibrolytic enzymes. J. Anim. Sci. 82, 198-208.

Wallace, R.J., Wallace, S.J.A., McKain, N., Nsereko, V.L., Hartnell, G.F., 2001. Influence of supplementary fibrolytic enzymes on the fermentation of corn and grass silages by mixed ruminal micro organisms in vitro. J. Anim. Sci. 79, 1905-1916.

Yang, W.Z., Beauchemin, K.A., Rode, L.M., 2000. A comparison of methods of adding fibrolytic enzymes to lactating cow diets. J. Dairy Sci. 83, 2512-2520.

Yu, P., McKinnon, J.J., Christensen, D.A., 2005. Improving the nutritional value of oat hulls for ruminant animals with pre-treatment of a multi enzyme cocktail: in vitro studies. J. Anim. Sci. 83, 1133-1141. 